\title{
Estimating farmers' stated willingness to accept pay for ecosystem services: case of Lake Naivasha watershed Payment for Ecosystem Services scheme-Kenya
}

\author{
J. M. Nyongesa*, H. K. Bett, J. K. Lagat and O. I. Ayuya
}

\begin{abstract}
Introduction: Lake Naivasha watershed is recognized for its contribution to Kenya's national gross domestic product from the export of horticultural products. Commercial horticultural investment downstream depends mainly on the Lake's water. The fresh water lake lacks surface outflow, and its recharge depends on river Malewa flowing from upper catchment in Aberdare ranges. However, unsustainable land use practices in the upper catchment has led to increasing sediment loading and pollution in river Malewa which affects water quality in the Lake downstream. Payment for Environmental Services (PES) scheme has been initiated as an alternative incentive approach to motivate upstream smallholder farmers adopt sustainable land use practices for conservation of watershed services. This paper analyzes willingness to accept pay (WTA) as proxy economic measure of environmental service (ES) value and determines socio-economic factors influencing farmers WTA for watershed conservation. We analyzed the WTA and characterized WTA underlying socio-economic determinants in two PES intervention sites in Kenya.

Methods: The objective of this study was to estimate WTA and determine socio-economic factors influencing WTA. Semi-structured questionnaire was used to collect data from 200 PES farmers through face-to-face interview. We applied contingent valuation (CV) and logistic regression for data analyses to elicit farmer's WTA estimates to implement PES farm practices and determine socio-economic factors influencing WTA, respectively.

Results: Results revealed over $90 \%$ of respondents were farmers and $60 \%$ had primary level of education. Average household farm size was 2.305 acres and family size was six members on average. We recorded a monthly marginal household increase in gross income from Kshs. 6891.969 (US\$68.92) before PES to Kshs. 11,011.48 (US\$110.12) with PES interventions. The estimated annual lowest and highest WTA for PES farm practices were at Kshs. 8835 (US\$88.35) for grass strip and Kshs. 21,847.500 (US\$218.48) for fallowing. Household socio-economic characteristics had significant influence on WTA among farmers.

Conclusions: The study revealed heterogeneity in WTA estimates among PES implementing farmers. The WTA reflects opportunity cost to farmers. We recommend PES mechanism as a policy tool to internalize negative watershed externalities to provide ecosystem services.
\end{abstract}

Keywords: Conservation, Ecosystem services, Livelihoods, Payment for Ecosystem Services, Practice, Watershed, Willingness to accept pay

\footnotetext{
* Correspondence: nyongesajm@yahoo.com

Department of Agricultural Economics and Agribusiness Management,

Egerton University, P.O. Box 536, 20115 Egerton-Njoro, Kenya
} 


\section{Introduction}

Development of ecosystem services concept can be traced to the late 1970-1980s with framing of beneficial ecosystem functions as services to increase public interest in biological diversity conservation (de Groot 1987). Since then, ecosystem service concept has gathered global interest including the Millennium Ecosystem (MEA 2003) and biodiversity (TEEB 2008) report. Since the release of the two reports, there has been increasing contribution to literature on ecosystem services (Fisher et al. 2009). Ecosystem service ${ }^{1}$ concept has been widely incorporated in socio-economic decision-making through increasing innovative marketbased conservation tools including Payment for Ecosystem Service (PES) schemes. The PES schemes have gained significant global attention as alternative approaches to improve environmental conservation and livelihood for sustainable production of ecosystem services in agroecosystem landscapes through alternative sustainable farming practices (Cole and June 2010). However, literature on ecosystem service valuation and PES integration in policy is still limited in Africa and Kenya in particular. Implementation of most PES programs is premised that ecosystem challenges are a result of market failure to recognize the value of positive externalities provided by natural ecosystems (Kosoy et al. 2007). However, PES schemes are generally direct payment incentives to ES providers based on provision of services demanded by buyers of ecosystem services (Zander et al. 2013) to conserve natural resources which are mainly public goods and services prone to destruction through overuse (Ferraro and Kiss 2002). The PES incentives encourage farmers to adopt sustainable farm practices in agricultural landscapes to internalize negative externalities for provision of ecosystem services (Pagiola et al. 2007).

Rural community famers mostly depend on agroecosystems for economic development through farming activities. However, continuous over-mining of natural resources and unsustainable farm practices leads to degradation of ecological health resulting in negative externalities primarily soil erosion, flooding, pollution, and silt loading of the water ecosystems. To reverse ecosystem degradation trends, conservation-livelihood enhancement tools like PES have been initiated as an alternative for watershed conservation through incentive mechanisms to farmers (Nyongesa 2011). Nonetheless, farmers are used to traditional farming practices, and to transform to sustainable PES interventions, their understanding of tradeoff between current and alternative farm practices, value of ecosystem services, and the expected benefits from alternative practices is imperative. The assumption is that farmers will accept pay to forego unsustainable current traditional farm practices if and only if they are convinced that the new bundle of practices will provide more benefits including increased productivity and income and improved agro-ecosystem condition. Some of the unsustainable farm practices in study sites include farming on high-gradient and riparian areas leading to increased soil erosion, overuse of agro-chemicals causing pollution, slash and burn of vegetation cover, cultivation across contours, and continuous cultivation of same land, reducing nutrient recycling. These practices accelerate degradation of agricultural ecosystem with negative significant impact on ecosystem services (Kitaka et al. 2002). PES incentives have been applied to motivate farmers to participate in implementation of PES scheme activities to reverse ecosystem degradation trends through upstream-downstream linkages to address environmental externalities upstream that affects downstream opportunities (Nepal et al. 2014).

Many studies have applied willingness to pay (WTP) approaches to estimate farmers' opportunity cost for alternative farm practices to increase productivity (Ulimwengu and Prabuddha 2011), when farmers have knowledge on agricultural products or ecosystem services prices. Our survey however valued ecosystem services based on willingness to accept pay (WTA) estimation approach premised on producer surplus concept. The WTA was modeled as opportunity cost to allow for farm restriction to maintain or increase agricultural productivity and rehabilitate landscapes for provision of ESs by sellers of ecosystem services. The WTA is more applicable to farmers selling the ES as opposed to WTP which would be more relevant for beneficiaries of ecosystem services (buyers of ecosystem services for Naivasha PES case). Likewise, contingent valuation method was applied in this study as non-market valuation technique which estimates benefits derived from ecosystem services (Carson and Groves 2007). Contingent methods utilizes stated preference techniques and are useful in assessment of ecosystem services valuation within total economic value (TEV) framework (DEFRA 2007) including use value (direct and indirect) and nonuse value (bequest and altruistic value). The contingent valuation $(\mathrm{CV})$ flexibility and strength to estimate total values allow estimates related to ecosystem services possible (Hanemann 1989, 1994).

This paper focused on farmer's WTA to implement PES practices and determinant factors influencing WTA as similarly applied in related study by Howard and Roe (2013). WTP approach has been widely used to value ecosystem services which can be provided by indigenous people in agro-ecosystems (Zander and Garnett 2011). Consequently, Willingness to pay has been applied mainly for situations where local communities pay for external services to sustain provision of ecosystem services. Conversely, some studies have applied monetary and conditional final bonus choice modelling to estimate WTA (Kuhfuss et al. 2015). This study applied CV approach to elicit farmers estimated WTA as proxy price attached to 
ecosystem services in surrogate market given that most ecosystem services lack a market for direct trading. To elicit "true" WTA without hypothetical bias is a known challenge faced in CV approaches (Loomis 2013). Having recognized this challenge, the authors applied ex ante techniques to reduce expected bias; first, the enumerators were trained to engage respondents in brief dialogue explaining the importance of the study and the need to have rational responses as this would have implication on future re-designing of similar PES approach they were implementing. Second, enumerators requested respondents to be sincere with their estimates based on the assumption that they were selling excludable goods in the market, and third, respondents were advised to give individual estimates and not figures they thought could be socially acceptable. Prior to the survey, the corresponding author had had worked with local communities to implement PES project and engaged Water Resource Users Associations (WRUAs) management communicating to them on the need to be honest in responses to avoid bias. This was communicated to all PES implementing farmers before sampling, stating to them that past similar social surveys had faced problems of overstating the responses leading to poor policy recommendations that would otherwise improve interventions designed to enhance conservation and farmers livelihoods. This "cheap" talk approach has similarly been used in several studies to reduce hypothetical bias linked to CV approaches, that is, advising farmers to respond assuming they are selling goods in common market, what price they would accept (Cummings and Taylor 1999).

The study focused on service providers as opposed to WTP studies which target buyers or beneficiaries of ESs. Asking farmers to state their WTA estimates for the farm opportunity cost to conserve watershed is the contingent valuation $(\mathrm{CV})$ of worth of that foregone land and/or land use practice to the individual farmers. Farmers and not public were targeted for responses given that they were land managers whose adoption of PES practices is envisaged to enhance ESs demanded by commercial agro-investors downstream. The WTA estimates indicate the economic value individual famer attaches to ecosystem goods and services in surrogate market place and offers an opportunity to attach price on previously un-priced ecosystems services (DEFRA 2013).

Lake Naivasha basin is rich in natural resources which drive socio-economic development at household and national levels. Smallholder farmers in the upper catchment depend on ecosystem services for their socioeconomic wellbeing primarily provisioning services for instance food. Similarly, commercial farmers downstream depend on flow of water from upstream sources to sustain their investments. However, unsustainable farm practices on smallholder farms upstream have led to degradation of natural resources impacting negatively on ecosystem service provision. The impact has contributed to food insecurity resulting from low farm productivity, decreased livelihood opportunities, and threat to downstream commercial investments that depend on quality water flow from upstream. Payment for Ecosystem Services was initiated through joint efforts of different stakeholders led by World Wide Fund for Nature and Care-Kenya as an alternative mechanism to rehabilitate degraded ecosystems. Even though there is an increasing global interest to apply PES as a successful policy tool for conservation and socio-economic development, information on ecosystem value and main drivers influencing WTA for PES conservation practices is still limited especially in Africa and specifically for PES scheme in Lake Naivasha basin (Nyongesa 2016). This study aimed at filling this gap.

Willingness to accept pay provides an alternative measure of wellbeing and ecosystem conservation linkage for PES scheme. Equally, characterizing WTA determinants reflects smallholder farm steward's perception on economic valuation of ecosystem services which is key for future design of PES schemes for sustainability. The PES scheme is a potential alternative policy tool to mitigate poverty and environmental challenges at local farm and regional level (Kisaka and Obi 2015) as ecosystem model option for sustainable land use management (Wang et al. 2015). Incentives to land managers would induce farmers to adopt farm practices which are less destructive but maintain agricultural lands thus creating business relationship between sellers and buyers of ecosystem services in proxy (Pagiola et al. 2005). The main objective of this study was to estimate WTA and determine socio-economic factors influencing farmers WTA to implement PES practices for provision of ecosystem services.

\section{Overview of PES scheme}

PES is a market-based scheme whose concept is based on the premise that those who provide environmental services (managers or sellers) by conserving natural ecosystems are compensated or incentivized by those who benefit from the services (the buyers). The term PES is used broadly aiming at ES enhancement through compensatory or rewards arrangement (van Noordwijk and Leimona (2010). However, Wunder (2005) and Engel et al. (2008) define PES as mechanisms which fits five sets of conditions; a voluntary transaction where, a welldefined environmental service (or land use likely to secure that service), is being "bought" by at least one buyer, from an environmental service provider, if, and only if, the environmental service provider secures environmental service provision (conditionality). The 
voluntary agreement between sellers and buyers of PES schemes is important, and incentives to farmers motivate them to sustainably adopt alternative PES farm practices (Ruto and Garrod 2009). Nevertheless, compensation or reward for environmental services (CRES) envisages efficient, equitable use and conservation of natural resources through contingent contracts between sellers and buyers of ecosystem services (Swallow et al. 2009).

However, PES ignores complex heterogeneity of ecosystems which undermines smooth market transactions (Kosoy and Corbera 2009). Conversely, Arild (2010) differentiated between generalizing PES and theory on market for ES as linked to the ES niche market leading to widely acceptable theoretical PES definition by Wunder (2005). Wunder's definition is related to Brendan et al. (2010) who characterized PES as mechanism linking conservation outcomes to market-based incentive approaches. The environmental services are majorly regarded as public goods, with less information on their value or pricing in a normal market place. Nonexcludability of these services limits direct marketing whose scarcity would provide warning sign of degradation and insufficiency unless there's total breakdown of ecosystems providing the service. The PES practices implemented by farmers in study sites were rehabilitation and maintenance of riparian zones through tree planting, grass strips, terracing along steep slopes, contour cropping, agro-forestry, clean improved seed varieties, crop rotation, fallowing, and reduction in agro-chemicals use. This study focused on these practices which are envisaged to rehabilitate degraded land targeted as hot spot farms. The WTA in this study characterizes the amount land managers were willing to accept to forego or limit unsustainable practices as trade-off with PES conservation interventions. Willingness to accept pay to adopt PES practices will enhance sustainable provisioning services such as adequate quality water demanded by buyers as ecosystem services downstream as well as food security and improved supporting services for instance soil nutrient cycling and regulating services including flood and soil erosion control, climate regulation, water purification, and pollination.

\section{Methods}

\section{Study site}

Lake Naivasha basin is located between $0^{\circ} 08^{\prime}$ to $0^{\circ} 46^{\prime} \mathrm{S}$ and $36^{\circ} 14^{\prime}$ to $36^{\circ} 43^{\prime} \mathrm{E}$ covering catchment average area of $3400 \mathrm{~km}^{2}$. The study covered two PES scheme implementing WRUAs; Upper Turasha Kinja located in Nyandarua South, Kinangop, Kipipiri Counties (intervention sites 1 and 2 in Fig. 1) and Wanjohi located in Kipipiri County (intervention site 5 in Fig. 1). The WRUAs cover main sub-basins of 639-Ha Tulaga area (Rivers Turasha and Kinja) and 4680-Ha Geta (River
Wanjohi) areas selected and prioritized sites in PES Naivasha project feasibility studies: hydrological (Gathenya 2007), livelihood-legal (Makenzi et al. 2007) and costbenefit analyses (WWF-CARE-Kenya 2007) prior to PES program initiation. Figure 1 shows the initially identified PES intervention sites in Lake Naivasha basin. Sites 1, 2, and 5 were prioritized as pilot hot spots for the current PES scheme. The study sites are mainly occupied by smallholder subsistence farmers who mainly depend on agroecosystems for their livelihood. The sites have undergone transformation over years of continuous cultivation and clearing of vegetation cover to expand agricultural land. Unsustainable farm practices have been the major source of degradation of ecosystems with negative impact on provision of ecosystem services.

The overall goal of Naivasha PES project is to improve the livelihoods of target households upstream in the Malewa river catchment of Lake Naivasha basin and secure green investment downstream. The PES project is implemented in the form of equitable payment for watershed services (EPWS) in reference to quality water as ecosystem service. The EPWS envisage benefiting communities directly through incentives from private sector downstream and indirectly from in situ benefits such as increased farm productivity and community empowerment to conserve ecosystems (WWF-CAREKenya 2007). Through PES interventions, upstream land owners manage their land to control soil erosion, reduce the use of agro-chemicals, conservation of riparian land, and grass stripping to retain soil envisaged to restore water quality and quantity water flow as an ecosystem service to benefit downstream commercial farmers who mainly depend on Lake Naivasha to sustain their horticulture business. Commercial farmers as beneficiary and buyers of watershed services therefore compensate upstream stewards for ESs provided.

\section{Sampling and data collection}

The selected sites were prioritized sub-basins to pilot PES project (Fig. 1) based on feasibility studies selection criteria including water yield, especially groundwater discharge, high-sediment yield, pollution threat/sources, high land use/land cover change, high population density with adverse changes in water quality, high water demand especially for irrigation, poverty levels where PES incentives would result in significant improvement of livelihood for the poor farmers, and existence of potential sellers and buyers of ecosystem services. Highly degraded farms were selected through community participation in selected sub-basins. Before PES project was initiated, cost-benefit analysis was conducted to establish the farmers' opportunity cost. However, cost-benefit analyses is based on aggregated values of gains and costs and fails to precisely consider how benefits and sacrifices 


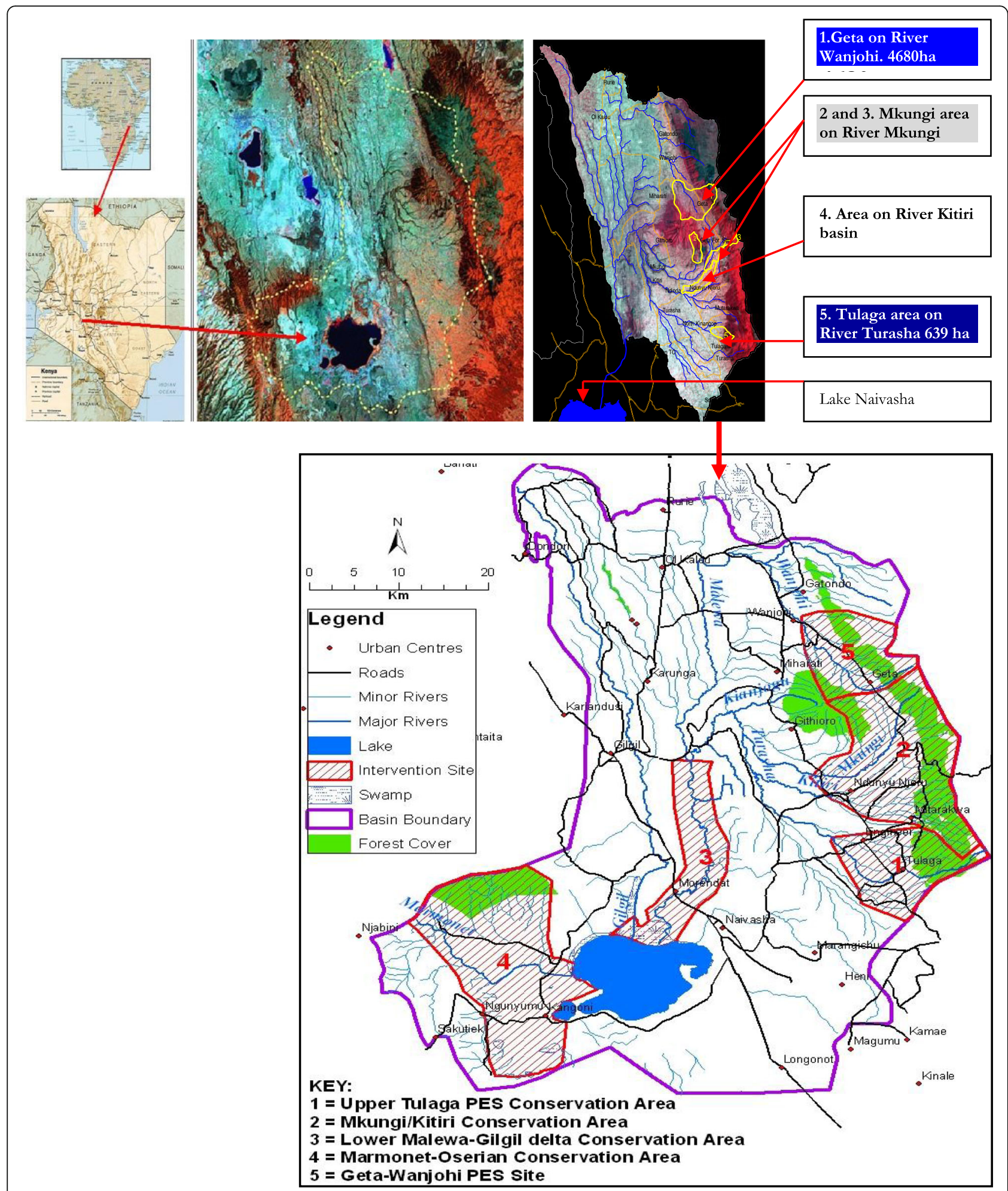

Fig. 1 The PES intervention sites within Lake Naivasha basin. Study sites are numbered 1 and 5. Source: modified from Gathenya 2007

are distributed across members of society (Gathenya 2007 and Makenzi et al. 2007).

This study applied the total economic value approach which economically elicits preferences for changes in the state of environment in monetary terms. We empirically determined sample size using the formula ${ }^{2}$ adopted from Kothari (2004) based on error margin of $5 \%$ to randomly select farmers from 9 out of 12 PES implementing zones 
to participate in this survey. Inclusion of non-PES practicing farmers, that is the general public in the study, was beyond scope of this study and therefore a gap for future studies. The study also intended to collect and assess data related to PES impact on project objectives of restoring ecological state of degraded farms to sustain ecosystem services including food (for food security) and water quality and quantity flow demanded by private investors to secure commercial investment downstream therefore balancing environmental conservation and economic development. We used two-stage sampling probability proportional to size to stratify the two WRUAs as primary sampling units. Nine study sites (four in Upper Turasha Kinja: Mutamaiyu, Kianguyo, Mutarakwa, and Tulaga and five in Wanjohi WRUA: Geta, Gitei-Gatondo, Kiamboga, Mikeu, and Rayeta) were purposively selected. A total of 200 households were randomly sampled from the initial 476 farmers in two WRUAs who started PES implementation in 2008. Primary data was collected using pre-tested semi-structured questionnaire through face-to-face interview. The questionnaire written in English was administered by local trained enumerators who translated in either Swahili or local dialect for easier response. We targeted the PES-implementing farmers, members of two WRUAs to assess change in their WTA from the current flat rate payment of annual Kshs. 1700 (USD 17) per farmer. Nevertheless, flat rate payment has been observed to encourage administrative ease and perceived as equitable in PES schemes (Sanchez et al. 2015).

However, when environmental services are restored by translating to incremental benefits from beneficiaries of ecosystem services (buyers), it is hypothesized that service sellers would tend to renegotiate for the increased pay with buyers. Based on this hypothesis, we asked farmers to elicit their WTA estimates considering the current payment modalities through voucher with cash value. Statistical software STATA version 12.0 was used to run logit regression analyses for empirical estimation of household stated WTA for the conservation PES land use practices.

\section{Description of the applied model}

Adopting the Holden and Shiferaw (2002) approach, WTA was modeled as an opportunity cost to allow for farm restrictions to maintain or increase agricultural productivity and improve environment conservation in the long run based on sellers of ES's utility function. To achieve the initial individual farmers' utility level, the equation is given as:

$$
V\left(I, \mathrm{EU}_{0} A_{0}\right)
$$

Where, $I$ is the vector of income, $\mathrm{EU}_{0}$ is the current expected utility level, and $A_{0}$ is the set of old agricultural farm practices and farm characteristics. It follows that WTA in order to sustain current productivity is stated as:

$$
\mathrm{WTA}_{i}=V\left(I, \mathrm{EU}_{0}, A_{0}\right)-V\left(I, \mathrm{EU}_{0}, A_{1}\right)
$$

WTA is the sum that leaves the household indifferent between the expected marginal utility under the old farm practices and the discounted expected marginal utility from change in future incomes as a result of the new set of PES conservation technology(s) $A_{1}$. The individual's maximization of expected utility in the long run will yield:

$$
E\left\{\begin{array}{c}
-U_{i 0}\left(C_{i 0}\right)+U_{i 0}\left(C_{i 0}-\mathrm{WTA}_{i}\right) \\
+\sum_{j=1}^{\infty}\left(1+\delta_{i}\right)^{-j} U_{i j}\left(C_{1 i j}-C_{0 i j}\right)
\end{array}\right\}=0
$$

Where $\delta i$ is the constant rate of household time preference, $C$ is the household consumption, and $U_{i j}\left(C_{1 i j}\right.$ $\left.C_{O i j}\right)$ is the utility level available to the ith household from the difference in land productivity induced by $j$ th PES conservation technology(s). WTA $\mathrm{W}_{\mathrm{i}}$ is the probability of the $i$ th farmer's WTA for $A_{1}$ PES practice. In many cases, WTA is almost always higher than WTP (Horowitz and McConnell 2003; Bett et al. 2009) and therefore not always equal such that:

WTA $\approx$ WTP + WTA $\frac{\partial W T P}{\partial y}$ leading to WTA and WTP relationship as derived by Sugden (1999), thus:

$$
\frac{\partial \mathrm{WTP}}{\partial y} \approx 1-\frac{\mathrm{WTP}}{\mathrm{WTA}}
$$

From Eq. 4, WTA estimation for this study was generalized following adoption from Bett et al. (2009) as:

$$
\begin{aligned}
\mathrm{WTA}_{i j} & =\alpha+\beta_{i} X_{i}+\cdots+\beta_{n} X_{n}+\varepsilon_{i j} \text { for is } \\
& =1 \cdots n
\end{aligned}
$$

where $\mathrm{WTA}_{i j}$ is the probability that the $i$ th household will accept pay to implement js PES conservation technology(s) influenced by $X_{i}$ vector of farm-farmer socio-economic characteristics, $n$ is the number of PES technologies while $\alpha$ and $\beta$ are parameters to be estimated. Based on revealed and stated preference techniques (contingent valuation), farmers were asked to reveal their WTA as surrogate market prices to implement PES practices for provision of ecosystem services. These were general questions to all farmers. The WTA is the average opportunity cost accepted to adopt PES practices to rehabilitate degraded land. Given the heterogeneity of farmer's choice for different PES practices, we applied Logit model framework essential to relax the assumption of independent irrelevant alternatives (IIA) associated with other models especially multinomial 
probit which alternatively could be used to analyze WTA. Likewise, dichotomous data in the study necessitated use of Logit model for data analysis. For derivation of econometric model, the assumption is that if a respondent's WTA is higher than the opportunity cost, then the respondent is likely to choose 'yes' and 'no' otherwise (Daniel et al. 2009) when presented with option to accept or reject pay for on-farm PES conservation practice. Similarly, Zilberman et al. (2008) found that potential WTP for ecosystem services by buyers of ESs strengthen further sustainability of PES scheme. Analysis of WTP was beyond scope of this study. The Logit model for WTA determinants is specified as follows:

$$
\begin{aligned}
\mathrm{WTA}_{i j}= & \beta_{0}+\beta_{1} S+\beta_{2} A+\beta_{3} E+\beta_{4} O+\beta_{5} F+\beta_{6} H \\
& +\beta_{7} K+\beta_{8} L+\beta_{9} A E+\ldots \beta_{12} C+\varepsilon
\end{aligned}
$$

where

$\mathrm{WTA}=\mathrm{Willingness}$ to Accept Pay to implement PES practices or otherwise; $\beta_{s}=$ vector of unknown parameters to be estimated; $\beta_{0}=$ constant coefficient (equation intercept) and respondent's: $S=$ gender; $A=$ age; $E=$ education level; $O=$ occupation; $F=$ farm size; $H=$ family size; $K=$ acquired skill and knowledge; $L=$ land use system; $\mathrm{AE}=$ access to extension services; $P=$ perception on PES impact on land rehabilitation; $I=$ income; $C=$ interest in conservation while $\varepsilon=$ random error term. Equations 5 and 6 therefore are linked to the results presented in Tables 3 and 4, respectively, that is, WTA estimates and analyses of socio-economic factors influencing farmer's WTA.

\section{Results}

\section{Household characteristics}

Table 1 profiles household's demographic statistics and indicates $67 \%$ and $33 \%$ of farmers interviewed were males and females, respectively. The mean age for household heads was 54 years while the average family size was six members. Household marginal gross income increased from Kshs. 6891.969 (US\$68.92) without PES to Kshs. 11,011.48 (US\$110.12) with PES interventions, a significant motivator to farmers on adoption of PES practices. Average farm size was 2.305 acres, which required rehabilitation to restore ecosystem services. Over $60 \%$ of farmers had primary education, $18.5 \%$ had achieved high school education, $1.5 \%$ had college/ university level of education while $17.5 \%$ had no formal education. Over $90 \%$ of households were mainly farmers while others were engaged in off-farm and employment activities.

\begin{tabular}{|c|c|c|c|}
\hline Variable description & Percent & Mean & Std. deviation \\
\hline Gender of household head & & .33 & \\
\hline Male & 67 & & \\
\hline Female & 33 & & \\
\hline Household head age & & 54.19 & 15.14 \\
\hline Household head education level & & & 0.65 \\
\hline None & 17.5 & & \\
\hline Primary & 62.5 & & \\
\hline High school & 18.5 & & \\
\hline College/university & 1.5 & & \\
\hline Occupation of the household head & & & 0.82 \\
\hline Employed & 1.5 & & \\
\hline Farmer & 93.0 & & \\
\hline Off-farm business & 0.5 & & \\
\hline Farmer and employed & 0.5 & & \\
\hline Farmer/employed/business & 1.0 & & \\
\hline Farmer/off-farm business & 3.5 & & \\
\hline Household family size & & 5.76 & 3.14 \\
\hline \multicolumn{4}{|l|}{$\begin{array}{l}\text { Household monthly income (Kshs.); } \\
1 \text { US\$ = Kshs. } 100 \text { at survey time }\end{array}$} \\
\hline Without/before PES farm practices & & 6891.96 & 5101.12 \\
\hline With/after PES farm practices & & $11,011.48$ & $14,719.42$ \\
\hline Household farm size (acres) & & 2.305 & 1.070 \\
\hline$N=200$ & & & \\
\hline
\end{tabular}

Table 1 Households demographic profiles

Willingness to continue implementing PES practices Table 2 presents results on willingness to continue implementing PES practices for watershed conservation. The results show that $97 \%$ of farmers were willing to continue implementing PES practices. For specific PES

Table 2 Willingness to continue implementing PES practices

\begin{tabular}{lll}
\hline Variable description & \multicolumn{2}{l}{ Statistic } \\
\cline { 2 - 3 }$(0=$ no; $1=$ yes $)$ & Mean & Std. error \\
\hline Willingness to implement all PES practices & 0.970 & .013 \\
Willingness to implement specific interventions & & \\
Rehabilitation and maintenance of Riparian Zones & 0.390 & .035 \\
Grass strips & 0.950 & .015 \\
Terracing & 0.150 & .025 \\
Contour cropping & 0.320 & .033 \\
Agro-forestry & 0.960 & .014 \\
Improved certified seed varieties & 0.620 & .034 \\
Fallowing & 0.370 & .034 \\
Crop rotation & 0.530 & .035 \\
Reduction in agrochemical use & 0.700 & .032 \\
Valid $N=200$ & & \\
\hline
\end{tabular}


practices, over $30 \%$ were willing to continue practicing rehabilitation and maintenance of riparian zones while $95 \%$ were willing to continues implementing grass strips, $15 \%$ for terracing, $32 \%$ for contour cropping, $96 \%$ for agro-forestry, $62 \%$ for clean improved seed varieties, $37 \%$ for fallowing, $53 \%$ for crop rotation technologies, and $70 \%$ for reduction in agrochemical use.

\section{Willingness to accept pay estimates}

The results displayed in Table 3 present WTA annual estimates to implement different PES farm practices for watershed conservation to restore ESs. The mean WTA estimate to conserve 1 acre of land set aside for conservation with no agricultural practices other than restricted grazing was Kshs. 21,902.50 (US\$219.025). The WTA estimates to implement specific PES practices varied for different PES practices; rehabilitation and maintenance of riparian land was Kshs. 9125.00 (US\$91.25); grass strips was Kshs. 8835.50 (US\$88.36); terracing Kshs. 16,534.00 (US\$165.35); contour cropping was estimated at Kshs. 11, 755.50 (US\$117.55); and agro-forestry at Kshs. 9821.50 (US\$98.22) while improved seed varieties was Kshs.14, 020.50 (US\$140.21). Fallowing attracted Kshs. 21,847.50 (US\$218.48); crop rotation had moderately low WTA of Kshs. 9,663.50 (US\$96.64) and WTA for agro-chemicals was priced at Kshs. 9707 (US\$97.07). Further probe revealed WTA for contour cropping estimated at Kshs. 11,755.50 (US\$117.55) and for agro-forestry at Kshs. 9821.50 (US\$98.22) while improved seed varieties was Kshs. 14,020.50 (US\$140.21).
Table 3 further display estimated average proxy cost attached to ecosystem services for restoration of degraded land. It was remarkable to note the cost farmers estimated to internalize negative ecosystems externalities without PES. Without PES scheme, soil erosion control, improved soil fertility, flood control, and land rehabilitation costs were estimated above Kshs. 11,000 (US\$110) annually. The estimates indicate the average amount farmers would save if ecosystems are conserved to offer the same natural services. The cost to control pests and diseases was estimated at Kshs. 3801 (US\$38.01).

\section{Socio-economic factors influencing farmer's WTA to provide ecosystem services}

Table 4 display Logit regression model estimates for socio-economic factors hypothesized to influence farmers' WTA to implement PES practices. Logit model was evaluated to determine for its goodness-of-fit indicated by the coefficient determination $R^{2}$ of 0.6301 . Education was significant factor at $1 \%$ level and was positively predicted to influence WTA. Household occupation was significant at $10 \%$ level whereas farm size was significant at $10 \%$ level; both variables showed weak positive association with WTA. Acquired skills and knowledge were significant factors and positively determined WTA at $5 \%$ level. Land use system was a significant WTA determinant at $5 \%$ level while farmer's perception of PES impact on farm productivity positively influenced WTA at $5 \%$ significant level. Income both as an incentive from buyers of ecosystem services and from in situ sources through increase in

Table 3 Estimated annual willingness to accept pay and cost to restore natural ecosystem services per 1 acre (1US\$=100Kshs.)

\begin{tabular}{|c|c|c|c|c|}
\hline Variable description & Statistic & & & \\
\hline Estimated WTA (Kshs.) & Min. & Max. & Mean & Std. Error \\
\hline WTA to conserve 1 acre $^{\text {a }}$ & 0.00 & $50,000.00$ & $21,902.50$ & 778.06 \\
\hline WTA to rehabilitate Riparian Zones & 1000.00 & $40,000.00$ & 9125.00 & 427.08 \\
\hline WTA for grass strips & 1000.00 & $20,000.00$ & 8835.50 & 307.75 \\
\hline WTA for terracing & 2500.00 & $55,000.00$ & $16,534.00$ & 719.62 \\
\hline WTA contour cropping & 2000.00 & $45,000.00$ & $11,755.50$ & 475.35 \\
\hline WTA for agro-forestry & 1500.00 & $35,000.00$ & 9821.50 & 408.91 \\
\hline WTA for clean improved seed & 1200.00 & $65,000.00$ & $14,020.50$ & 644.78 \\
\hline WTA for fallowing ${ }^{b}$ & 5000.00 & $45,000.00$ & $21,847.50$ & 723.51 \\
\hline WTA for crop rotation & 1500.00 & $85,000.00$ & 9663.50 & 503.56 \\
\hline WTA for reduction in agrochemical use & 1500.00 & & 9707.00 & 644.09 \\
\hline \multicolumn{5}{|c|}{ Estimated cost (Kshs.) to restore Ecosystem services on 1 acre without PES } \\
\hline Control soil erosion & 1000.00 & $100,000.00$ & $12,965.00$ & 936.19 \\
\hline Improve soil fertility & 1000.00 & $100,000.00$ & $11,815.00$ & 786.06 \\
\hline Control flooding & 1000.00 & $90,000.00$ & $11,215.00$ & 569.99 \\
\hline Control pests and diseases & 1000.00 & $15,000.00$ & 3801.00 & 164.31 \\
\hline
\end{tabular}

a Land for conservation only with agricultural practices restricted to activities like grazing

${ }^{\mathrm{b}}$ Restricted agricultural activities—no ploughing and limited activities like grazing allowed 
Table 4 Socio-economic factors influencing farmer's WTA to provide ESs

\begin{tabular}{|c|c|c|}
\hline \multicolumn{3}{|l|}{ Variable description } \\
\hline \multicolumn{3}{|l|}{ Willingness to accept pay (WTA) for ES provision ( $0=$ no; $1=$ yes) } \\
\hline & Coef. & Std. err. \\
\hline Gender of household head ( $0=$ male; $1=$ female) & 2.004 & 1.842 \\
\hline Age of household head (years) & -0.050 & 0.062 \\
\hline Education level of household head ( $0=$ none; 1 = primary; 2 = high school; $3=$ college/university) & $-4.926^{\mathrm{a}}$ & 2.184 \\
\hline $\begin{array}{l}\text { Occupation of Household head }(0=\text { not employed; } 1=\text { employed; } 2=\text { farmer; } \\
3=\text { off-farm business; } 4 \text { = farmer and employed; } 5=\text { farmer/employed/business; } \\
6=\text { farmer and off-farm business) }\end{array}$ & $-1.143^{\mathrm{a}}$ & 0.639 \\
\hline Farm size (acres) & 2.305 & 1.376 \\
\hline Household family size (number) & -0.308 & 0.329 \\
\hline Acquired skills/knowledge through PES ( $0=$ no; $1=$ yes $)$ & $6.048^{b}$ & 3.192 \\
\hline Land use system ( 0 = farming; 2 = not farming) & $3.312^{\mathrm{b}}$ & 1.680 \\
\hline Access to extension services & -1.7045 & 1.604 \\
\hline Perception on PES impact on land productivity ( $0=$ no; $1=$ yes $)$ & $6.083^{b}$ & 3.141 \\
\hline Income from PES ( $0=$ no; 1 =yes $)$ & $5.887^{\mathrm{a}}$ & 2.513 \\
\hline Conservation interest $(0=$ no; $1=$ yes $)$ & $-3.168^{c}$ & 1.945 \\
\hline _cons & -11.998 & 7.745 \\
\hline
\end{tabular}

productivity and returns on investment as a result of implementing alternative PES farm practices had strong positive influenced on WTA at $1 \%$ significance level. Interest to conserve environment demonstrated weak association with WTA at $10 \%$ significant level.

\section{Discussion}

This study aimed at assessing farmers' WTA as an opportunity cost to implement alternative PES farm practices to rehabilitate degraded agricultural lands for provision of ecosystem services. We also analyzed underlying socio-economic factors influencing WTA. Results presented are discussed below.

\section{Household characteristics}

The results in Table 1 for household demographics validate that household characteristics including income are significant factors to influence decisions on PES farm practices adoption. Additional household income enhances livelihood for the family and therefore are essential variables to influence decision on the adoption of PES practices perceived to increase income. Consequently, the results on education closely relate to Kenya's National Survey (GOK 2009) report indicating 48 and $27 \%$ of Kenya's population with primary and secondary education, respectively. The level of education was predicted to have a positive coefficient and important factor in acquiring knowledge and skills to implement PES farm transformation practices. Household occupation was predicted to have two-directional influences on WTA. First, farmers were hypothesized to readily accept pay for provision of ecosystem services for additional income because of available time to implement PES practices compared to those engaged in employment. Second, employed respondents could be indifferent on whether to accept pay and or otherwise influenced by expected additional income and time to spend on their own farm as well as off-farm employment. Results corroborate similar study findings by Schulz et al. (2014) who observed occupation to influence farmer's preference for alternative farm practices, and similarly, Zhen et al. (2014) found occupation as determinant of willingness to participate in Mongolia PES scheme among herders engaged in off-farm activities to earn extra income.

\section{Willingness to continue implementing PES practices}

The results in Table 2 on willingness to continue implementing PES practices imply significant importance farmers attached to PES farm practices. Similar studies (FAO 2011) have shown high willingness to restore ecological functions could be an indicator that PES can work in agriculture sector where ecosystem services are under threat and the opportunity costs for alternatives are not very high. However, Purvis et al. (1989) and Bond and Mayers (2010) demonstrated that farmers' willingness to continue implementing PES interventions 
is influenced by annual incentives as beneficial additionality on ecological conditions and farmer opportunity cost. Conversely, Robertson et al. (2015) observed that farmers' willingness to adopt new farm interventions that enhance sustainable ecosystem service provision depends on awareness creation, farmers' attitudes, and incentive availability. High number of farmers willing to implement different PES interventions implies PES practices acceptance and possible understanding that the alternative PES interventions could have positive influence on environment and household livelihoods. Riparian land is important to farmers due to provision of water sources especially during dry season to support related ecosystem service for instance crop farming for food security. Farmers' willingness to accept pay to implement grass strips is related to its dual purpose of soil and water conservation as well as provision of fodder for livestock. Low number of farmers (15\%) willing to accept pay to implement terracing is linked to different reasons ranging from high physical labour demand for mapping, marking, and digging terraces along with the high cost associated with the intervention. Contour cropping was a favoured practice by $32 \%$, and this is connected to less labour and skills required to implement the practice.

The high number (96\%) WTA for agro-forestry interventions is attributed to expected multiple benefits such as income, wood fuel, and regulating services especially those linked to soil and water conservation mainly flood and soil erosion control as well as climate moderation. Preference for clean certified seeds by $62 \%$ of farmers is associated with the expected benefits of high yields that contribute to food security and income while being resilient to effects of climate change and resistant to pests and diseases. It was remarkable to note low (37 \%) WTA for fallowing. This is correlated to small land parcels (2.305 acres) where fallowing would significantly affect food security due to lack of alternative land. Crop rotation was preferred by $53 \%$ because of its ability to reduce pests and disease prevalence associated with climatic changes and to improve soil structure and nutrient cycling which are important in supporting ecosystem services. Reduction in the use of agro-chemicals was highly accepted (70 \%) because of its potential to reduce environment pollution in agro-ecosystems and water bodies.

\section{Willingness to accept pay estimates}

The results in Table 3 reflect WTA estimates as proxy economic prices value and cost. The WTA to conserve 1 acre is the maximum incentive that ES producer accepts to derive utility from implementation of alternative PES farm practices. It is the sum that leaves the household indifferent between the expected marginal utility under the old farm practices and the discounted expected marginal utility from change in future benefits as a result of the new set of selected PES practice interventions. Ndetewio et al. (2013) has argued that WTA and WTP could vary with farm size as significant determinant factor on WTA-WTP for watershed services.

Since water quality and quantity were the main selling points in the agreement between buyers and sellers of ecosystem services, riparian land protection was therefore conditional for farmers to improve water quality. Riparian land proximity to water provides higher provisioning services like food during dry season and this influenced WTA estimates to restore degraded riparian land. Grass stripping practice has the advantage of significantly contributing to soil retention and providing fodder for livestock. The multiple benefits of the practice explain the low opportunity cost attached to grass strips implying high acceptance and adoption among farmers. High WTA for terracing reflects the unwillingness to carry out the practice because it is labour intensive and requires high skills to map and mark terraces along the slope land which is not favourable especially to female farmers. Low WTA for agro-forestry reflect high acceptance for the practice due to expected provision of multiple ecosystem services including provisioning services like food, regulating services including climate regulation, soil erosion, supporting service mainly soil retention, and cultural services for instance aesthetic values and recreation potential. The WTA for improved seed varieties relates to the significance attached to the practice for expected higher productivity and increased income for the households. Fallowing is not a practice favourable to farmers, and they would accept a high compensation of Kshs. 21,847.50 (US\$218.48) to leave the land for conservation. High WTA for fallowing shows best opportunity foregone if farmers had to set aside farm for only conservation. It reveals high economic value attached to the 1 acre of land by rural farming families to support their wellbeing. Crop rotation had moderately low WTA. The intervention requires minimal technical skills and is less costly and with less agricultural restrictions which explains its low WTA as indicator for high willingness to adopt. The WTA for agro-chemicals has two directional explanations: first, it was influenced by the requirement to prevent pollution as required under mutual ecosystem buyer-seller PES project; second was that more farmers were willing to implement PES farm practices with low requirement on use of agro-chemicals. Other related studies have indicated that where upstream opportunity costs are high and downstream benefits are low (Pagiola and Platais 2002), PES schemes tend to be unsustainable. Likewise, Ndetewio et al. (2013) found that equitable Payment for Ecosystem Services become sustainable and feasible if 
downstream benefits are high and upstream opportunity costs are low.

The proxy average estimates cost attached to ecosystem services to rehabilitate degraded land reflect avoidance cost, for instance, the cost farmers will avoid if they practised PES practices on their farms or the amount in economic terms farmers could spend to "replace" or restore degraded ecosystems in absence of PES practices. The cost mirrors the surrogate value attached to the ecosystem services including natural soil erosion and flood control, soil fertility restoration, and recycling. The value attached to rehabilitation practices reveals substitute market value estimates linked to ecosystem services particularly regulating services such as soil erosion, flood control, water purification, climate regulation, and pollination and supporting services for instance nutrient cycling, soil formation and retention, and habitat provision which directly or indirectly contribute to provisioning services essentially food and clean enough water. It is likely the cost to control pests and diseases could vary with different crop and livestock enterprises requirements on individual farms. Lower estimate for pests and disease control could be associated with limited information on available agro-chemicals and low household income allocated to basic family needs like food and health thus inadvertently leaving pests and disease prevalence to destroy crop and livestock enterprises the main sources of household income.

\section{Socio-economic factors influencing farmer's WTA to provide ecosystem services}

Socio-economic variables presented in Table 4 including education, occupation, acquired skills, land use practice, perception, income, and individual's interest for conservation were significant WTA determinants. Farmers with higher education level tend to have better understanding of PES concept and make informed decision when valuing ecosystem services compared to farmers without formal education. Results corroborate Chapika and Andreas (2009) study on WTA by upstream and downstream resource managers in Thailand Mae Sa watershed to engage in compensation schemes for ecosystem services provision. Likewise, Asrat and Belay (2004)) found education to have a significant influence on willingness decisions. Similarly, Aura (2016) observed positive correlation between farmers' education level and adoption of farm technologies.

Household occupation significance is associated with trade-offs farmers considered either working on their farms to implement PES practices versus time allocated for off-farm activities and formal employment. The incentive attached to PES scheme likely influenced WTA estimation because of the expected additional income. Because all selected farms for PES interventions were degraded with low productivity, PES practices and incentives were a solution to enhance productivity and income. Soil and water conservation skills and knowledge through farmer's capacity empowerment by government extension staff added an impetus to accept pay. In the absence of PES scheme, farmers could have paid for services for soil and water conservation capacity empowerment which explain the significance on WTA. Training associated with PES enhanced farmer's capacity to diversify on farm enterprises, useful to spread-out farm risks hence an attribute to influence WTA.

Significance of land use system is linked to expected income from PES practices as in situ benefits and incentives as pay from buyers of ESs. These are sources of additional income to offset on-farm costs thus influencing farmer's WTA to implement PES practices. Interventions that improved household livelihood influenced decisions on WTA. Regarding significance of farmer's perception about PES impact on farm productivity, the PES design aimed at rehabilitating degraded agro-ecosystems to restore provision of ecosystem services especially provisioning services like food and enough clean water required by sellers and buyers of the ESs, respectively. Provisioning services are directly linked to regulating and supporting services and restoration of ESs positively contribute to livelihood-ecosystem conservation nexus. This interaction elucidates the significance of PES impact on farm productivity as a WTA determinant.

Farm income was correctly predicted to have affirmative influence on WTA. Practices that increase household income sources will influence farmers' WTA and will induce farmers to adopt PES practices. This implies that the higher the income, the higher the probability of farmers accepting pay for PES practices. Farm and offfarm income have been observed from related studies to positively influence farmer's decisions to invest in agricultural interventions such as PES (Pender and Kerr 1998). Similarly, Faye and Deininger (2005) reported positive relationships between income and adoption of agricultural technologies. Marginal incremental change in income before and after PES interventions therefore convinced farmers to accept pay to implement PES practices for agro-ecosystem rehabilitation. The interest and need to conserve natural resources for sustainable provision of ecosystem services and livelihood enhancement were the main selling points linking sellers and buyers of ecosystem services therefore developing market for ESs that are not directly traded. This concern along with individual respondent's desire to restore ecological health through alternative PES practices clarifies conservation interest significance on WTA.

It was however remarkable to note that addition of more variables including household head age, sex, and 
family size and access to government extension services in the model yielded insignificant results. These results corroborate related study findings. For instance, Ulimwengu and Prabuddha (2011) similarly found access to extension service to be insignificant factor and tended to reduce farmers' WTP. All PES interventions in study sites were designed to restore degraded farms in the watershed and enhance additional livelihood opportunity benefits for farmers considering gender and age, and therefore, it was not surprising that outcome for sex and age variables had insignificant influence on WTA given that income is important across gender and age divide. Family size was equally insignificant factor to influence WTA. Interestingly, household family size had positive coefficient and was hypothesized to influence WTA contrary to the analyzed results. Socially, who makes household decisions for farm technologies in study sites could explain this outcome.

\section{Conclusions}

Lake Naivasha watershed is important in provision of ecosystem services which support socio-economic development at local and national level. The ecosystem degradation however threatens sustainability of this potential necessitating the need to develop market-based conservation-livelihood enhancement PES farm interventions. The PES incentive mechanism strengthens business relationship between local community's as ecosystem stewards upstream and beneficiaries of ecosystem services downstream through co-investment in good watershed management. Our research underscores WTA estimates and its underlying socio-economic determining factors under PES scheme in Lake Naivasha basin. We argue that the PES scheme has a potential to restore degraded agro-ecosystems and contribute to sustainable socio-economic development. Rehabilitation of landscapes is essential for the provision of ecosystem services, and PES is a potential tool through which economic valuation of ecosystem services can be assessed. We applied contingent valuation to estimate farmers WTA and Logit regression to model socio-economic factors influencing WTA to implement PES practices. Our study results demonstrate that different PES interventions can be applied as alternative sustainable farm practices to mitigate watershed negative externalities. We have shown that most farmers are willing to continue participating in PES scheme and are willing to accept pay as incentive in monetary form to implement PES farm practices relative to the current flat rate pay of Kshs. 1700 (US\$17) to mitigate degradation on their agricultural lands. We demonstrate that estimation of farmers WTA is a potential tool to attach economic value to ecosystem services as public non-rivalry goods and services to influence adoption of PES conservation farm practices vital for restoration of degraded landscapes. Acceptance of pay further confirms willingness to adopt the PES interventions to reverse the declining farm economic loses and to sustain environmental flows downstream. Significant number of farmers willing to continue participating in PES project implies that PES is a potential alternative policy tool to enhance conservation and livelihoods sustainability. Sustainable provision of ecosystems services is important for socio-economic development benefitting both local communities and private sector. The WTA to implement PES farm practices strengthen business linkages between downstream and upstream stakeholders through co-investment and collective responsibility in watershed management. Nevertheless, farmers are heterogeneous in their tastes and preference, which relates to socio-economic farm characteristics that influence WTA to implement alternative PES farm practices. This study revealed socio-economic factors including education, occupation, acquired skills, land use practice, perception, income, and individual's interest which significantly determined farmer's WTA. Findings provide useful information to conservation and development stakeholders to consider socio-economic characteristics when designing similar PES schemes as conservation and livelihood enhancement tools for sustainable adoption in degraded watersheds.

\section{Recommendations}

Based on the study results, we recommend that the adoption of PES practices needs to be enhanced through sensitization and training of farmers as sellers of ecosystem services. We further recommend institutionalizing PES as national conservation and livelihoods enhancement policy tool to conserve ecosystems for provision of ecosystem services. The PES policy need to be integrated within agricultural extension and related cross-sectoral extension services to improve farmer's skills and knowledge on conservationeconomic development linkages, on-farm decision-making, resource allocation, and strengthening smallholder farmersprivate sector relationship through developed markets for ecosystem services. Application of WTA technique to value ecosystem services is recommended for similar PES schemes for public-private stakeholder's recognition, understanding of natural ecosystems value, and assessment of the total gain in wellbeing from PES scheme as alternative conservation-livelihood policy. For sustainability and positive significant outcome on conservation and livelihoods, future design of similar PES schemes could consider socioeconomic characteristics as WTA determinants and important for seller-buyer bargaining for incentives to offset the opportunity cost incurred by farmers as sellers of ecosystem services. To strengthen the PES policy operational framework, local institutional governance and capacity building such as water resource users associations need to be improved to buttress conservation-livelihoods through integrated water and land ecosystem wide strategies scaled out to enhance upstream-downstream linkages. WTA for 
watershed services is an important tool to value ecosystem services. However, linkage between improved ecosystem status and ESs buyers willingness to pay (WTP) for improved ecosystem services in the PES study sites is imperative. This gap could be filled in future research through the assessment of buyers' WTP for ecosystem services as well as empirical determination of hydrological studies to confirm qualitatively observed water quality improvement as a result of PES farm practices.

\section{Endnotes}

${ }^{1}$ Ecosystem services are occasionally interchangeably used with environmental services. Ecosystem services are services provided by the natural environment that benefit people.

${ }^{2} n=\frac{Z^{2} P q N}{e^{2}(N-1)+Z^{2} P q}$ where; $n=$ sample size; $N=$ population size (number of PES households) $=476 ; P=$ population reliability (frequency estimated for a sample of size $n) ; q=0.5$ taken for all developing countries population and $p+q=1$ (where $q=1-p=0.5$ ); $e=0.050$ error margin considered in this study, $\mathrm{Z} \alpha / 2=$ normal reduced variable at 0.05 level of significance/confidence level, and $z$ is 1.96 . The sample size $n$ considered was determined as follows: $n=\frac{1.96^{2}(0.5 \times 0.5 \times 476)}{0.05^{2}(476-1)+1.96^{2} \times 0.5 \times 0.5}=\frac{457.15}{2.15}=213.63$ After data collection and cleaning, 13 questionnaires were detected as spoilt therefore discarded and 200 questionnaires were used for further synthesis and analyses.

\section{Acknowledgements \\ The authors thank all PES farmers who dedicated their time to participate in this study. The authors are particularly grateful to the World Wide Fund for nature and Water Resource Users association's staff for their support in providing documents and information relevant to the study and preparation of this manuscript. The authors are indebted to field enumerators who supported in data collection, the post graduate School Egerton University, Kenya for providing permission to conduct the research, and the University Library staff for supporting access to archived literature.}

\section{Authors' contributions}

JM served as research team leader responsible for designing the data collection interview schedule, data collection, analysis, and preliminary manuscript preparation. JK and HK served as research supervisors and were responsible for the overall guidance and supported in data analysis, interpretation, and edition approval of the manuscript for publication. OA provided valuable support in all stages of the manuscript preparation, conceptualization, and manuscript review. All authors read the manuscript, reviewed, endorsed final version, and agree to be responsible for manuscript preparation process and content and approval for submission to Ecological Processes Journal for publication.

\section{Competing interests}

The authors declare that they have no competing interests.

\section{Glossary}

Ecosystem

Natural unit of living things (flora and fauna, micro-organisms) and their PES physical environment (DEFRA 2007).

Payment for Environmental Services or Equitable Payment for Watershed Services EPWS in reference to water (watershed) is an incentive market-based scheme whose concept is premised that those who provide ecosystem services (managers or sellers) by conserving natural ecosystems are compensated by those who benefit from the services (buyers).

Total economic value (TEV)

The total gain in wellbeing from a policy measured by the net sum of the WTP or WTA (DEFRA 2007).

Use value

Value derived from using or having the potential to use a resource (net sum of direct, indirect, and option values). Value placed on having the option to use a resource in the future even if people are not current users) (DEFRA 2007)

Willingness to accept pay (WTA)

Monetary measure of the value of forgoing an environmental gain or allowing a loss (DEFRA 2007).

Willingness to pay (WTP) Monetary measure of the value of obtaining an environmental gain or avoiding a loss (DEFRA 2007).

Received: 5 July 2016 Accepted: 21 September 2016

Published online: 05 October 2016

\section{References}

Aura S (2016) Determinants of the adoption of integrated soil fertility management technologies in Mbale division, Kenya. African Journal of Food, Agriculture, Nutrition and Development 16(1):1-14. 10.18697/ajfand.73.15735.

Arild V (2010) An institutional analysis of payments for environmental services. Ecol Econ 69:1245-1252

Asrat PK, Belay HD (2004) Determinants of farmers' willingness to pay for soil conservation practices in the Southeastern Highlands of Ethiopia. Land Degrad Dev 15:423-438

Bett RC, Bett HK, Kahi AK, Peters KJ (2009) Evaluation and effectiveness of breeding and production services for dairy goat farmers in Kenya. Journal of Ecological Economics 68:2451-2460

Bond I, Mayers J (2010) Fair deals for watershed services: lessons from a multicountry action-learning project, Natural Resource Issues No. 13. IIED, London. ISBN: 978-1-84369-646-9 ISSN: 1605-1017. International Institute for Environment and Development (IIED) 13:1-122

Brendan F, Kulindwa K, Mwanyoka I, Turner RK, Burgess ND (2010) Common pool resource management and PES: lessons and constraints for water PES in Tanzania. Ecol Econ 69:1253-1261

Carson R, Groves T (2007) Incentive and informational properties of preference questions. Environ Resour Econ 37(1):181-210

Chapika S, Andreas N (2009) Willingness of upstream and downstream resource managers to engage in compensation schemes for environmental services. International Journal of the Commons 3(1):41-63, Igitur, Utrecht Publishing \& Archiving Services

Cole RJ, June (2010) Social and environmental impacts of payments for environmental services for agroforestry on small-scale farms in southern Costa Rica. Int J Sust Dev World 17(3):208-216

Cummings RG, Taylor LO (1999) Unbiased value estimates for environmental goods: a cheap talk design for the contingent valuation method. Am Econ Rev 89:649-665

Daniel V, Frank L, Michael DK (2009) Payment for ecosystem services: estimating demand within a tropical watershed. J Nat Resour Policy Res 1(2):189-202

DEFRA (2007) An introductory guide to valuing ecosystem services. Published by Department for Environment, Food and Rural Affairs. Nobel House, 17 Smith Square, London SW1P 3JR 12852, pp 9-34

DEFRA (2013) Payments for ecosystem services: a best practice guide. Department for Environment Food and Rural Affairs-DEFRA, URS 6-8 Greencoat Place, London SW1P 1PL, pp 1-84

de Groot RS (1987) Environmental functions as a unifying concept for ecology and economics. Environmentalist 7(2):105-109

Engel S, Pagiola S, Wunder S (2008) Designing payments for environmental services in theory and practice: an overview of the issues. Ecol Econ 65(4): 663-674

FAO (2011) Food and Agriculture Organization of the United Nations. Payments for Ecosystem Services and Food Security Report. Publishing Policy and Support Branch, Office of Knowledge Exchange, Research and Extension, FAO, Viale delle Terme di Caracalla, 00153 Rome, Italy, pp 1-300

Faye I, Deininger K (2005) Do new delivery systems improve extension access? Evidence from Rural Uganda. Paper presented at the American Agricultural 
Economics Association Annual Meeting, July 24-27, 2005 Providence, Rl, US. World Bank, 1818 H Street, NW - Washington DC, 20433 (USA), pp 1-31

Fisher B, Turner RK, Morling P (2009) Defining and classifying ecosystem services for decision making. Ecol Econ 68:643-653

Ferraro PJ, Kiss A (2002) Direct payments to conserve biodiversity. Science's Compass Policy forum 298:1-2

Gathenya JM (2007) Feasibility assessment for Naivasha-Malewa payments for watershed services: Jomo Kenyatta University of Agriculture and Technology Biomechanical and Ecosystem Engineering Department. Hydrological Assessment report submitted to WWF and CARE-Kenya PES Project- Kenya, pp 1-43

GoK (2009) Government of Kenya. Central Bureau of Statistics. Population and housing census "counting our people for the implementation of vision 2030" A, Government Printer 1:1-50

Hanemann WM (1989) Welfare evaluations in contingent valuation experiments with discrete response data. Am J Agric Econ 71(1):1057-1061

Hanemann WM (1994) Valuing the environment through contingent valuation. J Agricl Econ Perspect 8(4):19-43

Holden ST, Shiferaw B (2002) Poverty and land degradation: Peasants' willingness to Pay to sustain land productivity. Department of Economics and Social Sciences, Agricultural University of Norway, 7th edn. CAB International Publishing, New York, pp 91-102

Horowitz JK, McConnell K (2003) Willingness to accept, willingness to pay and the income effect. Department of Agricultural and Resource Economics. University of Maryland, College. Elsevier Journal of Economic Behavior \& Organization (51):537-545

Howard G, Roe B (2013) Stripping because you want to versus stripping because the money is good: a latent class analysis of farmer preferences regarding filter strip programs. Department of Economics, East Carolina University. Paper prepared for presentation at the Agricultural \& Applied Economics Association's 2013 AAEA \& CAES Joint Annual Meeting, Washington, DC, August 4-6, 2013, pp 1-32

Kisaka L, Obi A (2015) Farmers' preferences for management options as payment for environmental services scheme. International Food and Agribusiness Management Review (IFAMA) 18(3):1-22

Kitaka N, Harper DM, Mavuti KM, Pacini N (2002) Chemical characteristics, with particular reference to phosphorus, of the rivers draining into Lake Naivasha, Kenya. Hydrobiogia 488:57-71

Kosoy N, Martinez-Tuna M, Muradian R, Martinez-Alier J (2007) Payments for environmental services in watersheds: insights from a comparison study of three cases in Central America. Ecol Econ 61:446-455

Kosoy N, Corbera E (2009) Payments for ecosystem services as commodity fetishism. J Ecol Econ 69:1228-1236

Kothari CR (2004) Research methodology, quantitative techniques. Vikas Publishing House Ltd, New Delhi, pp 64-179

Kuhfuss L, Préget R, Thoyer S, Hanley N (2015) Nudging farmers to sign agrienvironmental contracts: the effects of a collective bonus. Discussion papers in Environmental Economics University of St. Andrews. Discussion papers in Environmental Economics. University of St. Andrews, 2015-06, Department of Geography and Sustainable Development, Scotland, pp 1-22

Loomis J.B (2013) Strategies for overcoming hypothetical bias in stated preference surveys. Journal of Agricultural and Resource Economics. Western Agricultural Economics Association ISSN 1068-5502.39(1):34-46

Makenzi P, Mutinda M, Omollo J (2007) Establishing a Business Case between Providers and Consumers of Watershed Services. Payment for Watershed Services, Local Legal Level and Livelihoods Study of Malewa River Basin, Naivasha. Payment for Watershed Services-Local Legal Level and Livelihoods Study of Malewa River Basin, Naivasha, pp 1-87

MEA (2003) Millennium Ecosystem Assessment, 2003. Ecosystems and Human Well-being. A Report of the Millennium Ecosystem Assessment. A Framework for Assessment. The Millenium Ecosystem Assessment Series, ISBN 1-59726040-1, Island Press. World Resources Institute, Washington DC, pp 1-155

Nepal S, Flügel WA, Shrestha A B (2014) Upstream-downstream linkages of hydrological processes in the Himalayan region. Ecological Processes 3(19):116

Nyongesa JM (2011) Payment for ecosystem services: an integrated approach to natural resource management and livelihood improvement. A case of Lake Naivasha-Malewa river basin sub-catchment, Kenya. A paper presented at the $10^{\text {th }}$ African Crop Science Society Conference, Joaquim Chissano Internacional Conference Centre, 10-13 October 2011 Maputo-Mozambique. Printed in Uganda ISSN1023-70X/2011, 10:1-410:479-484
Nyongesa JM (2016) Payment for environmental services: land use transformation influence on livelihood-environment nexus and environmental services value in Lake Naivasha Watershed, Kenya. PhD Thesis. Egerton University (in press), pp 1-92.

Ndetewio PI, Mwakaje AG, Mujwahuzi M, Ngana J (2013) Factors influencing willingness to pay for watershed services in lower Moshi, Pangani Basin, Tanzania. Institute of Resource Assessment University of Dar es salaam. International Journal of Agriculture and Environment ISSN 2: 2307-2652(2):1-19

Pender JL, Kerr JM (1998) Determinants of farmers indigenous soil and water conservation investments in semi-arid India. Elsevier Journal of Agricultural Economics 19(1998)113-12519:113-125

Pagiola S, Platais G (2002) Payment for ecosystem services. The environment strategy notes. World Bank EnvironDep 3:1-4

Pagiola S, Ramírez E, Gobbi J, Haan C, Ibrahim M, Murgueitio E, Ruíz JP (2007) Paying for the environmental services of silvopastoral practices in Nicaragua. Ecol Econ 64:374-385

Pagiola S, Arcenas A, Platais G (2005) Can Payments for environmental services help reduce poverty? An exploration of the issues and the evidence to date from Latin America. World Dev 33(2):237-253

Purvis A, Hoehn J, Sorenson V, Pierce F (1989) Farmers' response to a filter strip program: results from a contingent valuation survey. J Soil Water Conserv 44(1989):501

Robertson GP, Gross KL, Hamilton SK, Landis DA, Schmidt TM, Snapp SS, Swinton SM (2015) Farming for ecosystem services: an ecological approach to production agriculture. The ecology of agricultural landscapes: long-term research on the path to sustainability. Oxford University Press, New York, USA, pp 33-53

Ruto E, Garrod G (2009) Investigating farmers' preferences for the design of agrienvironment schemes: a choice experiment approach. J Environ Plan Manag 52:631-647

Sanchez RM, Maldonado JH, Wunder S, Almanza CB (2015) Heterogeneous users and willingness to pay in an ongoing payment for watershed protection initiative in the Colombian Andes. Ecol Econ 75:126-134

Schulz N, Breustedt G, Latacz-Lohmann U (2014) Assessing farmers' willingness to accept "greening": insights from a discrete choice experiment in Germany. J Agric Econ 65(1):26-48

Sugden R (1999) "Alternative to the neoclassical theory of choice": valuing ecosystem preferences: theory and practice of the contingent valuation method in the US, EU and developing countries (lan Bateman and K.G Willis, editors). Oxford University Press, London, ISBN 0198288530

Swallow BM, Kallesoe MF, Iftikhar UA, van Noordwijk M, Bracer C, Scherr SJ, Raju KV, Poats SV, Duraiappah AK, Ochieng BO, Mallee H, Rumley R (2009) Compensation and rewards for environmental services in the developing world: framing pan-tropical analysis and comparison. ICRAF Working Paper no. 32. Nairobi-Kenya: World Agroforestry Centre. $14(2): 1-59$

TEEB (2008) The economics of ecosystems and biodiversity. An interim report. Welzel + Haedt, wesseling,Germany. A Banson Production,Cambridge,UK ISBN-13978-92-79-08960-2, pp 1-68

Ulimwengu J, Prabuddha S (2011): Joint estimation of farmers' stated willingness to pay for agricultural services. The International Food Policy Research Institute (IFPRI) Discussion Paper 01070.West and Central Africa Office, pp 1-28

van Noordwijk M, Leimona B (2010) CES/COS/CIS paradigms for compensation and rewards to enhance environmental services. ICRAF Working Paper No. 100. World Agro forestry Centre. Bogor, Indonesia, pp 1-43

Wang Z, Zongming W, Zhang B, Lu C, Ren C (2015) Impact of land use/land cover changes on ecosystem services in the Nenjiang River Basin, Northeast China. EcologicalProcesses. doi:10.1186/s13717-015-0036-y $4(11): 1-12$

Wunder S (2005) Payments for environmental services; some nuts and bolts. CIFOR Occasional paper 42. Centre for International Forestry Research, Bogor, Indonesia. Center for International Forestry Research CIFOR Infobrief 42(9):1-4

WWF-CARE-Kenya (2007) Upstream cost benefit analysis of the payment for watershed services. Research report prepared for WWF/CARE project for Environment Conservation in the River Malewa Catchment Areas, pp 1-33

Zander KK, Parkes R,Straton A, Garnett ST (2013) Water ecosystem services in Northern Australia-how much are they worth and who should pay for their provision?. PLoS ONE 8(5): e64411 
Zander KK, Garnett ST (2011) The economic value of environmental services on indigenous-held lands in Australia. PLoS ONE 6(8):e23154. doi:10.1371/journal. pone.0023154. Accessed 22 Aug 2016

Zhen L, Li F, Yan HG, Liu H, Liu J Y, Zhang HY, Du BZ, Wu R Z, Sun CZ, Wang C (2014) Herders' willingness to accept versus the public sector's willingness to pay for grassland restoration in the Xilingol League of Inner Mongolia, China. IOP Publishing Ltd. Environmental Research Letters 9(4):1-15

Zilberman D,Lipper L, McCarthy N (2008) When could payments for ecosystem services benefit the poor? Environment and Development Economics 13(3): $255-278$

\section{Submit your manuscript to a SpringerOpen ${ }^{\circ}$ journal and benefit from:}

- Convenient online submission

- Rigorous peer review

- Immediate publication on acceptance

- Open access: articles freely available online

- High visibility within the field

- Retaining the copyright to your article

Submit your next manuscript at $>$ springeropen.com 